\title{
Psychromonas japonica sp. nov., Psychromonas aquimarina sp. nov., Psychromonas macrocephali sp. nov. and Psychromonas ossibalaenae sp. nov., psychrotrophic bacteria isolated from sediment adjacent to sperm whale carcasses off Kagoshima, Japan
}

Correspondence

Miyazaki Masayuki

miyazakim@jamstec.go.jp

\section{Masayuki Miyazaki, Yuichi Nogi, Yoshihiro Fujiwara and Koki Horikoshi}

The XBR Group, Japan Agency for Marine-Earth Science and Technology, 2-15 Natsushima-cho, Yokosuka 237-0061, Japan
Four novel species of psychrotrophic bacteria were isolated from sediment adjacent to sperm whale carcasses off Kagoshima, Japan, at a depth of 228-250 m. Cells of the five isolated strains, JAMM 0394 ${ }^{\top}$, JAMM 0404 ${ }^{\top}$, JAMM 0415 ${ }^{\top}$, JAMM 0700 and JAMM 0738 ${ }^{\top}$, were Gram-negative, rod-shaped, non-sporulating and motile by means of a single polar flagellum. The novel strains were able to produce isoprenoid quinone Q-8 as the major component. The predominant fatty acids were $C_{16: 0}$ and $C_{16: 1}$. Phylogenetic analysis based on $16 S$ rRNA gene sequences showed that the novel strains represent a separate lineage within the genus Psychromonas. The $\mathrm{G}+\mathrm{C}$ contents of the novel strains were 38.8-42.8 mol\%. DNA-DNA hybridization values between these strains and reference strains of the genus Psychromonas were significantly lower than that generally accepted as the threshold for the phylogenetic definition of species. The names

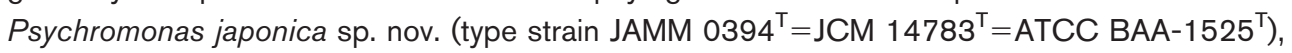
Psychromonas aquimarina sp. nov. (type strain JAMM $0404^{\top}=\mathrm{JCM} 14784^{\top}=$ ATCC BAA$1526^{\top}$ ), Psychromonas macrocephali sp. nov. (two strains, type strain JAMM $0415^{\top}=\mathrm{JCM}$ $14785^{\top}=$ ATCC BAA-1527 ${ }^{\top}$ ) and Psychromonas ossibalaenae sp. nov. (type strain JAMM $0738^{\top}=\mathrm{JCM} 14786^{\top}=$ ATCC BAA-1528 $8^{\top}$ ) are proposed.
The genus Psychromonas was proposed by Mountfort et al. (1998) for a novel psychrophilic and aerotolerant anaerobic bacterium that belonged to the class Gammaproteobacteria. The genus includes piezophilic and halophilic species that are widely distributed in nature, especially in aquatic environments such as polar sea ice, high-salinity ponds and the ocean (Kawasaki et al., 2002; Nogi et al., 2002; Groudieva et al., 2003; Xu et al., 2003; Auman et al., 2006; Nogi, 2007). Seven species of the genus Psychromonas have been described to date. We investigated a sperm whale carcass ecosystem off Kagoshima, Japan, for three years between 2003 and 2005 (Fujiwara et al., 2007).

\footnotetext{
Abbreviation: ASW, artificial seawater.

The GenBank/EMBL/DDBJ accession numbers for the 16S rRNA gene sequences of the five strains described in this paper are AB304804AB304808.

Transmission electron micrographs of negatively stained cells of the four novel species and a table detailing the results of DNA-DNA hybridization experiments between the novel strains and closely related species of the genus Psychromonas are available as supplementary material with the online version of this paper.
}

About 800 aerobic bacteria were isolated from the sediment adjacent to the sperm whale carcasses, of which five strains were related to the genus Psychromonas. In this paper, we describe the results of taxonomic studies on these isolates. Several lines of evidence indicate that these isolates represent four novel species within the genus Psychromonas.

The five strains, JAMM $0394^{\mathrm{T}}$, JAMM $0404^{\mathrm{T}}$, JAMM $0415^{\mathrm{T}}$, JAMM 0700 and JAMM $0738^{\mathrm{T}}$, were collected from marine sediment adjacent to sperm whale carcasses by the unmanned ROV Hyper Dolphin off Kagoshima, Japan (dive no. $189,31^{\circ} 20.720^{\prime} \mathrm{N} 129^{\circ} 59.285^{\prime} \mathrm{E}$; dive no. 192 , $31^{\circ} 20.730^{\prime} \mathrm{N} 129^{\circ} 59.314^{\prime} \mathrm{E}$; dive no $193,31^{\circ} 20.716^{\prime} \mathrm{N}$ $129^{\circ} 59.284^{\prime} \mathrm{E}$; dive no $328,31^{\circ} 20.722^{\prime} \mathrm{N} 129^{\circ} 59.283^{\prime} \mathrm{E}$; dive no. $330,31^{\circ} 18.518^{\prime} \mathrm{N} 129^{\circ} 59.372^{\prime} \mathrm{E}$ ) at a depth of 228-250 m during cruises NT03-08 and NT04-08. The sediment samples were collected by the ROV's manipulator and placed in the sample holder of the sterilized sampler. A portion of each sample was cultivated in marine agar 2216 (MA; Difco) at $15{ }^{\circ} \mathrm{C}$ for approximately 7 days. The bacteria were maintained on MA plates or in marine broth 
2216 (MB; Difco) at $20{ }^{\circ} \mathrm{C}$ and stored at $-80{ }^{\circ} \mathrm{C}$ in $15 \%$ (v/v) glycerol. Psychromonas antarctica DSM $10704^{\mathrm{T}}$ and Psychromonas ingrahamii CIP $108865^{\mathrm{T}}$ were used as reference strains. Unless otherwise indicated, physiological tests (Baumann et al. 1972; Barrow \& Feltham 1993) were performed with a slight modification that used artificial seawater (ASW; $1 \times \mathrm{ASW}$ consisted of $2.75 \% \mathrm{NaCl}, 0.07 \%$ $\mathrm{KCl}, 0.54 \% \mathrm{MgCl}_{2} .6 \mathrm{H}_{2} \mathrm{O}, 0.68 \% \mathrm{MgSO}_{4} .7 \mathrm{H}_{2} \mathrm{O}, 0.14 \%$ $\mathrm{CaCl}_{2} \cdot 2 \mathrm{H}_{2} \mathrm{O}$ and $\left.0.02 \% \mathrm{NaHCO}_{3}\right)$. Growth at various temperatures $\left(0-30{ }^{\circ} \mathrm{C}\right)$ was measured in $\mathrm{MB}$. The novel strains retained viability for about 7 days at the optimal temperature $\left(20{ }^{\circ} \mathrm{C}\right)$. Growth at various $\mathrm{NaCl}$ concentrations was examined in medium containing $0.5 \%$ peptone (Difco), $0.5 \%$ yeast extract (Difco) and $0.32 \%$ $\mathrm{MgSO}_{4} \cdot 7 \mathrm{H}_{2} \mathrm{O}$, with $\mathrm{NaCl}$ concentrations of $0-7 \%$ (w/v). The optimal $\mathrm{pH}$ and $\mathrm{pH}$ range for growth were determined in media containing $0.5 \%$ peptone, $0.5 \%$ yeast extract, $0.32 \% \mathrm{MgSO}_{4} \cdot 7 \mathrm{H}_{2} \mathrm{O}$ and $3.0 \% \mathrm{NaCl}(\mathrm{w} / \mathrm{v})$ with $\mathrm{pH}$ adjusted to 5.5, 6.0, 6.5, 7.0, 7.5, 8.0, 8.5, 9.0, 9.5, 10.0 and 10.5. Acid production from sugars was assessed using modified O/F medium (Hugh \& Leifson, 1953) containing $0.5 \times \mathrm{ASW}, 0.1 \%\left(\mathrm{NH}_{4}\right)_{2} \mathrm{SO}_{4}, 0.1 \%$ yeast extract (Difco), $0.1 \%$ Tris, $1.4 \% \mathrm{NaCl}, 1 \%$ sugar and $0.006 \%$ bromothymol blue ( $\mathrm{pH}$ adjusted to 7.2 at $20{ }^{\circ} \mathrm{C}$ ) and incubated at the optimum temperature. Oxidase activity was determined by spreading cell pellets on oxidase test paper (Nissui Pharmaceutical). Catalase activity was determined based on bubble production in $3 \%(\mathrm{v} / \mathrm{v}) \mathrm{H}_{2} \mathrm{O}_{2}$ solution. Gelatinase, protease, amylase and lipase activities were detected on MA plates using substrate concentrations of $1 \%(\mathrm{w} / \mathrm{v})$. DNase activity was assessed using DNase test agar (Difco). Hydrogen sulfide production from thiosulfate and the production of indole were assessed using SIM medium (Nissui Pharmaceutical) stabs prepared with $0.5 \times$ ASW instead of water.

Transmission electron microscopy of negatively stained cells was performed as described by Nogi et al. (1998). Cells of strains JAMM $0394^{\mathrm{T}}$, JAMM $0404^{\mathrm{T}}$, JAMM $0415^{\mathrm{T}}$ and JAMM $0738^{\mathrm{T}}$ grown in MA at the optimal temperature and in the mid-exponential phase of growth were used for electron microscopic observations (JEM-1210; JEOL).

Cellular fatty acids were extracted and analysed as described by Komagata \& Suzuki (1987). The novel strains were cultured in $\mathrm{MB}$ at the optimal temperatures and fatty acids were extracted using the method of Miyazaki et al. (2006). Isoprenoid quinones were extracted with chloroform/methanol $(2: 1)$ from dried cells $(200 \mathrm{mg})$ and purified by TLC. The purified isoprenoid quinones were analysed using reversed-phase HPLC (Komagata \& Suzuki, 1987).

Chromosomal DNA was purified according to a standard method (Saito \& Miura, 1963). The DNA G + C content was determined using reversed-phase HPLC (Tamaoka \& Komagata, 1984). For analysis of relatedness, DNA-DNA hybridization was carried out at $41{ }^{\circ} \mathrm{C}$ for $4 \mathrm{~h}$ and measured fluorometrically using the method of Ezaki et al. (1989). 16S rRNA and gene sequences were obtained by direct sequencing of PCR-amplified DNA as described previously (Miyazaki et al., 2008). Nucleotide substitution rates $\left(K_{\text {nuc }}\right)$ (Kimura, 1980) were determined and a distance matrix tree was constructed with the neighbourjoining method (Saitou \& Nei, 1987) using the CLUSTAL_X program (Thompson et al., 1997). Alignment gaps and unidentified base positions were not taken into consideration in the calculations. The topology of the phylogenetic tree was evaluated by performing bootstrap analysis with 1000 replicates. The GenBank/DDBJ/EMBL accession numbers for the $16 \mathrm{~S}$ rRNA gene sequences of the novel isolates are shown in Fig. 1. Other reference sequences were obtained from the GenBank database.

Cultural, physiological and biochemical characteristics of the novel isolates are shown in Table 1 or given in the species descriptions below. Cells of the novel strains were Gram-negative, non-sporulating rods that were motile by means of a single polar unsheathed or sheathed flagellum (see Supplementary Fig. S1 in IJSEM Online). Colonies on MA were circular with entire edges, smooth and convex. The novel strains were facultatively anaerobic chemoorganotrophs and the major isoprenoid quinone type was Q-8. Detailed physiological and biochemical characteristics of the novel strains are shown in Table 1 and in the species descriptions.

The whole-cell fatty acid contents of the novel and reference strains are shown in Table 2. The cultivation temperatures of the strains differed and thus the fatty acids of these strains were analysed after growth at the optimal temperatures for the strains. The major fatty acids detected for the novel strains were $C_{16: 0}$ and $C_{16: 1}$. The fatty acid profiles of the novel strains showed only low levels of similarity with those of the reference strains. For example, strain JAMM $0394^{\mathrm{T}}$ contained only small amounts of $\mathrm{C}_{14: 0}$ and $\mathrm{C}_{15: 0}$, but did not contain $\mathrm{C}_{22: 6}$, strain JAMM $0404^{\mathrm{T}}$ contained small amounts of $\mathrm{C}_{14: 0}$ and $\mathrm{C}_{15: 0}$, strain JAMM $0415^{\mathrm{T}}$ contained small amounts of $\mathrm{C}_{14: 0}$ and strain JAMM $0738^{\mathrm{T}}$ contained small amounts of $\mathrm{C}_{14: 0}$ and $\mathrm{C}_{22: 6}$.

The $\mathrm{G}+\mathrm{C}$ contents of the novel strains and those of other species of the genus Psychromonas are shown in Table 1. The results of the phylogenetic analyses using $16 \mathrm{~S}$ rRNA gene sequences are shown in Fig. 1. These results support the conclusions described below and further clarify the taxonomic and phylogenetic positions of the novel strains in the genus Psychromonas. Strains JAMM 0394 ${ }^{\mathrm{T}}$, JAMM $0415^{\mathrm{T}}$, JAMM 0700 and JAMM $0738^{\mathrm{T}}$ were most closely related to $P$. antarctica DSM $10704^{\mathrm{T}}(97.2-98.0 \%$ gene sequence similarity). Strain JAMM $0404^{\mathrm{T}}$ was most closely related to $P$. ingrahamii CIP $108865^{\mathrm{T}}$ ( $97.3 \%$ similarity). The generally recognized criteria for delineating bacterial species state that strains with a DNA-DNA relatedness of less than $70 \%$, as measured by hybridization, represent separate species (Wayne et al., 1987). The results of DNADNA hybridization analysis (see Supplementary Table S1 in IJSEM Online) of the novel strains and reference strains 


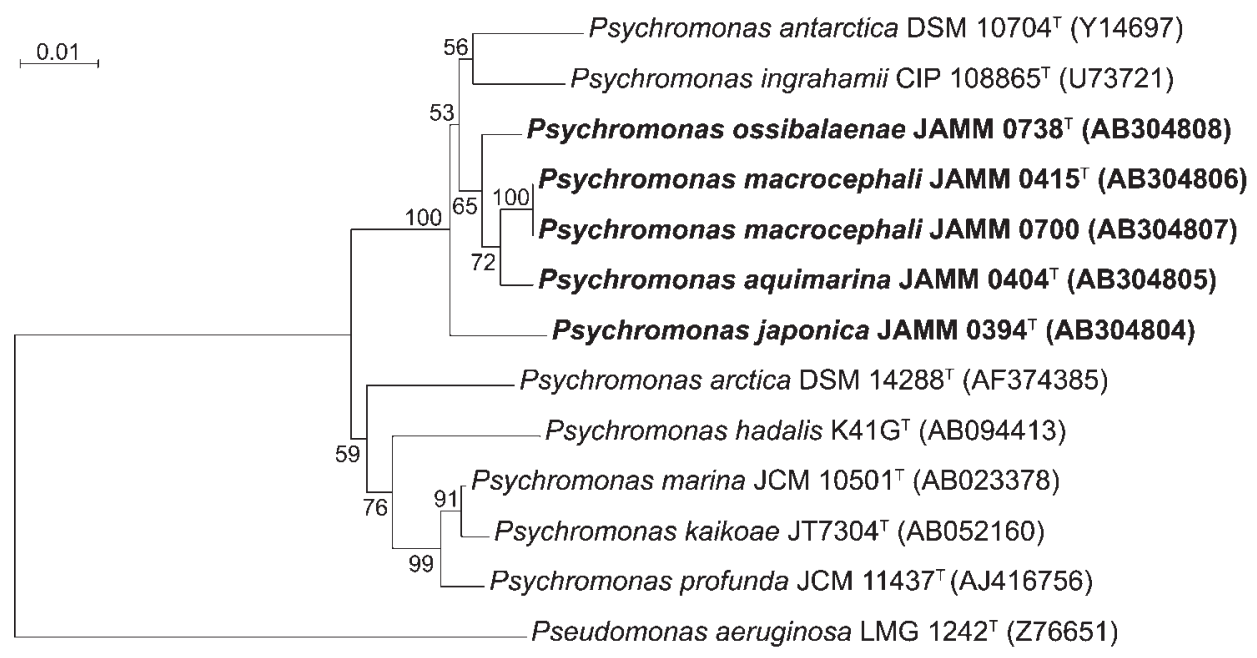

Fig. 1. Phylogenetic tree, constructed using the neighbour-joining method and based on 16S rRNA gene sequences, showing the relationships of the five novel strains within the genus Psychromonas and related genera. The percentage of 1000 bootstrap resamplings that support branching points above $50 \%$ confidence is indicated. Bar, 0.01 nucleotide substitution per site.

showed that the DNA-DNA relatedness was less than $47 \%$, which is significantly lower than that generally accepted as the phylogenetic definition of a species. This suggests that the isolated strains represent novel species of the genus Psychromonas.

The five isolated strains are psychrotrophic and, on the basis of the phenotypic, genotypic and phylogenetic data, evidently represent novel species within the genus Psychromonas. We therefore propose the names Psychromonas japonica sp. nov., Psychromonas aquimarina sp. nov., Psychromonas macrocephali sp. nov. and Psychromonas ossibalaenae sp. nov. for these new strains.

\section{Description of Psychromonas japonica sp. nov.}

Psychromonas japonica (ja.pon'i.ca. N.L. adj. japonica pertaining to Japan, where the isolate originated).

Cells are rod-shaped; cell width ranges from 0.5 to $0.8 \mu \mathrm{m}$ and cell length ranges from 1.6 to $2.2 \mu \mathrm{m}$. Cells are Gramnegative and are motile by means of a single polar flagellum. Colonies on MA are circular with entire edges, smooth, convex and translucent cream-coloured. Colonies on MA are $0.5-1.0 \mathrm{~mm}$ in diameter after 1-2 days of incubation at $20{ }^{\circ} \mathrm{C}$. The bacteria are psychrotrophic. The optimal growth temperature is $20-22{ }^{\circ} \mathrm{C}$. Growth occurs at 5 and $25{ }^{\circ} \mathrm{C}$, but not at $0{ }^{\circ} \mathrm{C}$ or above $27{ }^{\circ} \mathrm{C}$. Optimal growth occurs in the presence of $3 \% \mathrm{NaCl}(\mathrm{w} / \mathrm{v})$. Growth occurs in the presence of $2 \%$ and $5 \% \mathrm{NaCl}$, but not without $\mathrm{NaCl}$ or in the presence of $>6 \% \mathrm{NaCl}$. The optimal $\mathrm{pH}$ value for growth is $\mathrm{pH}$ 9.0. Growth occurs at $\mathrm{pH} 6.5$ and $\mathrm{pH} 9.5$, but not at $\mathrm{pH} 6.0$ or at greater than pH 10.0. Facultatively anaerobic and capable of respiratory metabolism. The catalase and cytochrome oxidase tests are positive. Does not produce $\mathrm{H}_{2} \mathrm{~S}$ or indole. Nitrate is reduced to nitrite, but nitrite is not reduced. DNase is positive. Gelatin is weakly hydrolysed. Protease, amylase and lipase tests are negative. Hydrolysis of Tween 20 is positive, but hydrolysis of Tween 40, Tween 80 and ONPG is negative. Acid is formed oxidatively from cellobiose, Dfructose, D-glucose and D-mannose. No acid is produced from L-arabinose, D-galactose, glycerol, myo-inositol, Dlactose, maltose, D-mannitol, raffinose, L-rhamnose, Dsorbitol, sucrose, trehalose or xylose. The $\mathrm{G}+\mathrm{C}$ content of the DNA is about $38.8 \mathrm{~mol} \%$ (determined by HPLC). The major isoprenoid quinone is Q-8. The dominant cellular fatty acids are $\mathrm{C}_{16: 0}$ and $\mathrm{C}_{16: 1}$.

The type strain, JAMM $0394^{\mathrm{T}}\left(=\mathrm{JCM} 14783^{\mathrm{T}}=\right.$ ATCC BAA- $1525^{\mathrm{T}}$ ), was isolated from the sediment adjacent to a sperm whale carcass off Kagoshima, Japan.

\section{Description of Psychromonas aquimarina sp. nov.}

Psychromonas aquimarina (a.qui.ma.ri' na. L. n. aqua water; L. adj. marinus of the sea; N.L. fem. adj. aquimarina of/ from seawater).

Cells are rod-shaped; cell width ranges from 0.9 to $1.1 \mu \mathrm{m}$ and cell length ranges from 1.6 to $3.2 \mu \mathrm{m}$. Cells are Gramnegative and are motile by means of a single polar sheathed flagellum. Colonies on MA are circular with entire edges, smooth, convex and cream-coloured. Colonies on MA are $1.0-2.0 \mathrm{~mm}$ in diameter after 1-2 days of incubation at $20{ }^{\circ} \mathrm{C}$. The bacteria are psychrotrophic. The optimal growth temperature is $20-25{ }^{\circ} \mathrm{C}$. Growth occurs at 5 and $27{ }^{\circ} \mathrm{C}$, but not at $0{ }^{\circ} \mathrm{C}$ or above $30{ }^{\circ} \mathrm{C}$. Optimal growth occurs in the presence of $3 \% \mathrm{NaCl}(\mathrm{w} / \mathrm{v})$. Growth occurs in the presence of $2 \%$ and $5 \% \mathrm{NaCl}$, but not without $\mathrm{NaCl}$ or in the presence of $>6 \% \mathrm{NaCl}$. The optimal $\mathrm{pH}$ value for growth is $\mathrm{pH}$ 8.5. Growth occurs at $\mathrm{pH} 6.0$ and $\mathrm{pH} 9.0$, 
Table 1. Differential characteristics of species of the genus Psychromonas

Taxa: 1, Psychromonas japonica sp. nov. JAMM $0394^{\mathrm{T}} ; 2$, Psychromonas aquimarina sp. nov. JAMM $0404^{\mathrm{T}}$; 3 , Psychromonas macrocephali sp. nov. JAMM $0415^{\mathrm{T}}$; 4, Psychromonas ossibalaenae sp. nov. JAMM $0738^{\mathrm{T}} ; 5$, P. antarctica DSM $10704^{\mathrm{T}} ; 6$, P. ingrahamii CIP $108865^{\mathrm{T}}$. Cells of all species are Gram-negative and the major isoprenoid quinone type is Q-8. The following tests were positive for all taxa: oxidase activity and utilization of Dfructose and D-glucose. The following tests were negative for all taxa: production of indole and utilization of L-arabinose, myo-inositol, D-lactose and D-sorbitol. +, Positive; -, negative; w, weakly positive; ND, no data; TC, translucent cream; C, cream; w, white. Data are from this study, Mountfort et al. (1998), Nogi et al. (2002) and Auman et al. (2006).

\begin{tabular}{|c|c|c|c|c|c|c|}
\hline Characteristic & 1 & 2 & 3 & 4 & 5 & 6 \\
\hline \multicolumn{7}{|l|}{ Cell } \\
\hline Shape & Rods & Rods & Rods & Rods & Ovoid rods & Large rods \\
\hline Colony colour & $\mathrm{TC}$ & $\mathrm{C}$ & $\mathrm{C}$ & $\mathrm{C}$ & $\mathrm{W}$ & $\mathrm{W}$ \\
\hline Motility & + & + & + & + & + & - \\
\hline \multicolumn{7}{|l|}{ Growth at/in: } \\
\hline $10 \% \mathrm{NaCl}(\mathrm{w} / \mathrm{v})$ & - & - & - & - & - & + \\
\hline $\mathrm{pH} 9.0$ & + & + & + & + & - & - \\
\hline Catalase & + & - & - & - & + & + \\
\hline Gelatinase & $\mathrm{W}$ & + & + & - & + & - \\
\hline Protease & - & $\mathrm{W}$ & + & - & ND & ND \\
\hline Amylase & - & + & - & - & + & - \\
\hline Tween 40 & - & + & + & - & ND & ND \\
\hline Tween 80 & - & + & + & - & ND & $\mathrm{ND}$ \\
\hline ONPG test & - & + & + & + & ND & ND \\
\hline Nitrate reduction to nitrite & + & + & + & + & - & + \\
\hline \multicolumn{7}{|l|}{ Utilization as carbon source: } \\
\hline Cellobiose & + & - & - & + & + & + \\
\hline D-Galactose & - & + & + & + & + & + \\
\hline Glycerol & - & + & + & + & - & + \\
\hline Maltose & - & + & + & + & + & $\mathrm{ND}$ \\
\hline D-Mannitol & - & + & - & - & + & + \\
\hline D-Mannose & + & + & + & + & $\mathrm{w}$ & - \\
\hline
\end{tabular}

but not at $\mathrm{pH} 5.5$ or at greater than $\mathrm{pH} 9.5$. Facultatively anaerobic and capable of respiratory metabolism. The cytochrome oxidase test is positive, but catalase is negative. Does not produce $\mathrm{H}_{2} \mathrm{~S}$ or indole. Nitrate is reduced to nitrite, but nitrite is not reduced. Gelatinase, amylase and DNase are positive. Protease is weakly positive. Lipase is negative. Hydrolysis of Tween 20, Tween 40, Tween 80 and ONPG is positive. Acid is formed oxidatively from Dfructose, D-galactose, D-glucose, glycerol, maltose, Dmannitol, D-mannose, sucrose and trehalose. No acid is produced from L-arabinose, cellobiose, myo-inositol, Dlactose, raffinose, L-rhamnose, D-sorbitol or xylose. The G+C content of the DNA is about $42.2 \mathrm{~mol} \%$ (determined by HPLC). The major isoprenoid quinone is Q-8. The dominant cellular fatty acids are $\mathrm{C}_{16: 0}$ and $\mathrm{C}_{16: 1}$.

The type strain, JAMM $0404^{\mathrm{T}}\left(=\mathrm{JCM} 14784^{\mathrm{T}}=\right.$ ATCC BAA- $1526^{\mathrm{T}}$ ), was isolated from the sediment on the seabed adjacent to a sperm whale carcass off Kagoshima, Japan.

\section{Description of Psychromonas macrocephali sp. nov.}

Psychromonas macrocephali (mac.ro.ceph'a.li. N.L. gen. n. macrocephali of Physeter macrocephalus, the Latin name for the sperm whale). 
Table 2. Fatty acid contents of the novel strains and other members of the genus Psychromonas

Taxa: 1, P. japonica sp. nov. JAMM $0394^{\mathrm{T}}$; 2, P. aquimarina sp. nov. JAMM $0404^{\mathrm{T}} ; 3$, P. macrocephali sp. nov. JAMM $0415^{\mathrm{T}} ; 4, P$. ossibalaenae sp. nov. JAMM $0738^{\mathrm{T}} ; 5$, P. antarctica DSM $10704^{\mathrm{T}} ; 6, P$. ingrahamii CIP $108865^{\mathrm{T}}$. tr, Trace $(<1 \%)$. Data are from this study, Nogi et al. (2002) and Auman et al. (2006).

\begin{tabular}{|lcccccc|}
\hline Fatty acid & $\mathbf{1}$ & $\mathbf{2}$ & $\mathbf{3}$ & $\mathbf{4}$ & $\mathbf{5}$ & $\mathbf{6}$ \\
\hline $\mathrm{C}_{12: 0}$ & $\operatorname{tr}$ & 3.6 & 4.0 & $\operatorname{tr}$ & 1 & 2.5 \\
$\mathrm{C}_{14: 0}$ & 2.0 & 1.5 & 1.3 & 1.9 & - & - \\
$\mathrm{C}_{15: 0}$ & 5.0 & 2.8 & $\operatorname{tr}$ & $\operatorname{tr}$ & - & - \\
$\mathrm{C}_{16: 0}$ & 21.7 & 28.9 & 26.7 & 25.4 & 24 & 18.7 \\
$\mathrm{C}_{14: 1}$ & 7.3 & 4.3 & 4.5 & 5.1 & 8 & - \\
$\mathrm{C}_{16: 1}$ & 52.5 & 49.0 & 51.0 & 55.5 & 58 & 67 \\
$\mathrm{C}_{18: 1}$ & 2.7 & 1.8 & 4.3 & 1.4 & 3 & 3.6 \\
$\mathrm{C}_{22: 6}$ & - & $\operatorname{tr}$ & $\operatorname{tr}$ & 1.2 & - & - \\
$\mathrm{C}_{14: 0} 3-\mathrm{OH}$ & 6.2 & 7.2 & 7.5 & 8.4 & 6 & $4.5^{*}$ \\
\hline
\end{tabular}

${ }^{*} \mathrm{C}_{12: 0}$ alde, $\mathrm{C}_{16: 1}$ iso or $\mathrm{C}_{14: 0} 3-\mathrm{OH}$.

Cells are rod-shaped; cell width ranges from 0.6 to $0.8 \mu \mathrm{m}$ and cell length ranges from 2.2 to $2.9 \mu \mathrm{m}$. Cells are Gramnegative and are motile by means of a single polar sheathed flagellum. Colonies on MA are circular with entire edges, smooth, convex and cream-coloured. Colonies on MA are $1.0-2.0 \mathrm{~mm}$ in diameter after 12 days of incubation at $20{ }^{\circ} \mathrm{C}$. The bacteria are psychrotrophic. The optimal growth temperature is $20^{\circ} \mathrm{C}$. Growth occurs at $0{ }^{\circ} \mathrm{C}$ and $25^{\circ} \mathrm{C}$, but not above $27{ }^{\circ} \mathrm{C}$. Optimal growth occurs in the presence of $3 \% \mathrm{NaCl}(\mathrm{w} / \mathrm{v})$. Growth occurs in the presence of $2 \%$ and $6 \% \mathrm{NaCl}$, but not without $\mathrm{NaCl}$ or in the presence of $>7 \% \mathrm{NaCl}$. The optimal $\mathrm{pH}$ value for growth is $\mathrm{pH}$ 8.5. Growth occurs at $\mathrm{pH} 6.0$ and $\mathrm{pH} 9.0$, but not at $\mathrm{pH} 5.5$ or at greater than $\mathrm{pH}$ 9.5. Facultatively anaerobic and capable of respiratory metabolism. The cytochrome oxidase test is positive, but catalase is negative. Does not produce $\mathrm{H}_{2} \mathrm{~S}$ or indole. Nitrate is reduced to nitrite, but nitrite is not reduced. Gelatinase, protease and DNase are positive, but amylase and lipase are negative. Hydrolysis of Tween 20, Tween 40, Tween 80 and ONPG is positive. Acid is formed oxidatively from D-fructose, D-galactose, D-glucose, glycerol, maltose, D-mannose and trehalose. No acid is produced from L-arabinose, cellobiose, myo-inositol, Dlactose, D-mannitol, raffinose, L-rhamnose, D-sorbitol, sucrose or xylose. The $\mathrm{G}+\mathrm{C}$ content of the DNA is about $41.5 \mathrm{~mol} \%$ (determined by HPLC). The major isoprenoid quinone is Q-8. The dominant cellular fatty acids are $\mathrm{C}_{16: 0}$ and $\mathrm{C}_{16: 1}$.

The type strain, JAMM $0415^{\mathrm{T}}\left(=\mathrm{JCM} \quad 14785^{\mathrm{T}}=\right.$ ATCC BAA- $1527^{\mathrm{T}}$ ), was isolated from the sediment adjacent to a sperm whale carcass off Kagoshima, Japan. Strain JAMM 0700 is a reference strain.

\section{Description of Psychromonas ossibalaenae sp. nov.}

Psychromonas ossibalaenae (os.si.ba.la.e.na'e. L. n. os ossis bone; L. n. balaena -ae whale; N.L. gen. n. ossibalaenae of a bone of a whale).

Cells are rod-shaped; cell width ranges from 0.7 to $1.1 \mu \mathrm{m}$, and cell length ranges from 1.9 to $3.7 \mu \mathrm{m}$. Cells are Gramnegative and are motile by means of a single polar flagellum. Colonies on MA are circular with entire edges, smooth, convex and cream coloured. Colonies on MA are $1.0-2.0 \mathrm{~mm}$ in diameter after 1-2 days of incubation at $20{ }^{\circ} \mathrm{C}$. The bacteria are psychrotrophic. The optimal growth temperature is $20{ }^{\circ} \mathrm{C}$. Growth occurs at 0 and $25^{\circ} \mathrm{C}$, but not above $27^{\circ} \mathrm{C}$. Optimal growth occurs in the presence of $3 \% \mathrm{NaCl}(\mathrm{w} / \mathrm{v})$. Growth occurs in the presence of $2 \%$ and $5 \% \mathrm{NaCl}$, but not without $\mathrm{NaCl}$ or in the presence of $>6 \% \mathrm{NaCl}$. The optimal $\mathrm{pH}$ value for growth is $\mathrm{pH}$ 9.0. Growth occurs at $\mathrm{pH} 6.5$ and at $\mathrm{pH} 9.5$, but not at $\mathrm{pH} 6.0$ or at greater than $\mathrm{pH}$ 10.0. Facultatively anaerobic and capable of respiratory metabolism. The cytochrome oxidase test is positive, but catalase is negative. Does not produce $\mathrm{H}_{2} \mathrm{~S}$ or indole. Nitrate is reduced to nitrite, but nitrite is not reduced. DNase and lipase are positive, but gelatinase, protease and amylase are negative. Hydrolysis of ONPG is positive, but that of Tween 20, Tween 40 and Tween 80 is negative. Acid is formed oxidatively from cellobiose, D-fructose, D-galactose, Dglucose, glycerol, maltose, D-mannose, sucrose, trehalose and xylose. Acid is weakly formed oxidatively from raffinose. No acid is produced from L-arabinose, myoinositol, D-lactose, D-mannitol, L-rhamnose or D-sorbitol. The $\mathrm{G}+\mathrm{C}$ content of the DNA is about $41.3 \mathrm{~mol} \%$ (determined by HPLC). The major isoprenoid quinone is Q-8. The dominant cellular fatty acids are $\mathrm{C}_{16: 0}$ and $\mathrm{C}_{16: 1}$.

The type strain, JAMM $0738^{\mathrm{T}}\left(=\mathrm{JCM} \quad 14786^{\mathrm{T}}=\mathrm{ATCC}\right.$ BAA- $1528^{\mathrm{T}}$ ), was isolated from the sediment adjacent to a sperm whale carcass off Kagoshima, Japan.

\section{Acknowledgements}

We would like to thank Mr Katsuyuki Uematsu and Ms Tomoko Takahashi for assistance in preparing electron micrographs. We are very grateful to the ROV Hyper Dolphin operation team and the crew of the R/V Natushima for helping us to collect the deep-sea samples.

\section{References}

Auman, A. J., Breezee, J. L., Gosink, J. J., Kampfer, P. \& Staley, J. T. (2006). Psychromonas ingrahamii sp. nov., a novel gas vacuolate, psychrophilic bacterium isolated from Arctic polar sea ice. Int J Syst Evol Microbiol 56, 1001-1007.

Barrow, G. I. \& Feltham, R. K. A. (1993). Cowan and Steel's Manual for the Identification of Medical Bacteria, 3rd edn. Cambridge: Cambridge University Press.

Baumann, L., Baumann, P., Mandel, M. \& Allen, R. D. (1972). Taxonomy of aerobic marine eubacteria. J Bacteriol 110, 402-429. 
Ezaki, T., Hashimoto, Y. \& Yabuuchi, E. (1989). Fluorometric deoxyribonucleic acid-deoxyribonucleic acid hybridization in microdilution wells as an alternative to membrane filter hybridization in which radioisotopes are used to determine genetic relatedness among bacterial strains. Int J Syst Bacteriol 39, 224-229.

Fujiwara, Y., Kawato, M., Yamamoto, T., Yamanaka, T., Sato-Okoshi, W., Noda, C., Tsuchida, S., Komai, T., Cubelio, S. S. \& other authors (2007). Three-year investigations into sperm whale-fall ecosystems in Japan. Mar Ecol 28, 219-232.

Groudieva, T., Grote, R. \& Antranikian, G. (2003). Psychromonas arctica sp. nov., a novel psychrotolerant, biofilm-producing bacterium isolated from Spitzbergen. Int J Syst Evol Microbiol 53, 539-545.

Hugh, R. \& Leifson, E. (1953). The taxonomic significance of fermentative versus oxidative metabolism of carbohydrates by various gram-negative bacteria. J Bacteriol 66, 24-26.

Kawasaki, K., Nogi, Y., Hishinuma, M., Nodasaka, Y., Matsuyama, H. \& Yumoto, I. (2002). Psychromonas marina sp. nov., a novel halophilic, facultatively psychrophilic bacterium isolated from the coast of the Okhotsk Sea. Int J Syst Evol Microbiol 52, 1455-1459.

Kimura, M. (1980). A simple method for estimating evolutionary rates of base substitutions through comparative studies of nucleotide sequences. J Mol Evol 16, 111-120.

Komagata, K. \& Suzuki, K. (1987). Lipid and cell-wall analysis in bacterial systematics. Methods Microbiol 19, 161-207.

Miyazaki, M., Nogi, Y., Usami, R. \& Horikoshi, K. (2006). Shewanella surugensis sp. nov., Shewanella kaireitica sp. nov. and Shewanella abyssi sp. nov., isolated from deep-sea sediments of Suruga Bay, Japan. Int J Syst Evol Microbiol 56, 1607-1613.

Miyazaki, M., Nogi, Y., Fujiwara, Y., Kawato, M., Kubokawa, K. \& Horikoshi, K. (2008). Neptunomonas japonica sp. nov., an Osedax japonicus symbiont-like bacterium isolated from sediment adjacent to sperm whale carcasses off Kagoshima, Japan. Int J Syst Evol Microbiol 58, 866-871.

Mountfort, D. O., Rainey, F. A., Burghardt, J., Kaspar, H. F. \& Stackebrandt, E. (1998). Psychromonas antarcticus gen. nov., sp. nov., a new aerotolerant anaerobic, halophilic psychrophile isolated from pond sediment of the McMurdo Ice Shelf, Antarctica. Arch Microbiol 169, 231-238.

Nogi, Y. (2007). Chapter 5. Bacteria in the Deep Sea: Psychropiezophiles. In Psychrophiles From Biodiversity to Biotechnology, pp. 73-82. Edited by R. Margesin, F. Schinner, J. C. Marx \& C. Gerday. New York: Springer.

Nogi, Y., Kato, C. \& Horikoshi, K. (1998). Taxonomic studies of deepsea barophilic Shewanella strains and description of Shewanella violacea sp. nov. Arch Microbiol 170, 331-338.

Nogi, Y., Kato, C. \& Horikoshi, K. (2002). Psychromonas kaikoae sp. nov., a novel piezophilic bacterium from the deepest coldseep sediments in the Japan Trench. Int J Syst Evol Microbiol 52, 15271532.

Nogi, Y., Hosoya, S., Kato, C. \& Horikoshi, K. (2007). Psychromonas hadalis sp. nov., a novel piezophilic bacterium isolated from the bottom of the Japan Trench. Int J Syst Evol Microbiol 57, 1360-1364.

Saito, H. \& Miura, K. (1963). Preparation of transforming deoxyribonucleic acid by phenol treatment. Biochim Biophys Acta 72, 619-629.

Saitou, N. \& Nei, M. (1987). The neighbor-joining method: a new method for reconstructing phylogenetic trees. Mol Biol Evol 4, 406425.

Tamaoka, J. \& Komagata, K. (1984). Determination of DNA base composition by reversed-phase high-performance liquid chromatography. FEMS Microbiol Lett 25, 125-128.

Thompson, J. D., Gibson, T. J., Plewniak, F., Jeanmougin, F. \& Higgins, D. G. (1997). The CLUSTAL_X windows interface: flexible strategies for multiple sequence alignment aided by quality analysis tools. Nucleic Acids Res 25, 4876-4882.

Wayne, L. G., Brenner, D. J., Colwell, R. R., Grimont, P. A. D., Kandler, O., Krichevsky, M. I., Moore, L. H., Moore, W. E. C., Murray, R. G. E. \& other authors (1987). International Committee on Systematic Bacteriology. Report of the ad hoc committee on reconciliation of approaches to bacterial systematics. Int J Syst Bacteriol 37, 463-464.

Xu, Y., Nogi, Y., Kato, C., Liang, Z., Ruger, H.-J., De Kegel, D. \& Glansdorff, N. (2003). Psychromonas profunda sp. nov., a psychropiezophilic bacterium from deep Atlantic sediments. Int J Syst Evol Microbiol 53, 527-532. 